\title{
Corpos indóceis e suas práticas políticas
}

\section{Indocile bodies and the political practices}

Amabilis de Jesus da Silva 1

Universidade Estadual do Paraná

\section{Resumo}

Busca-se refletir sobre os modos de abordagem do controle/descontrole em algumas práticas artísticas, partindo-se de três pressupostos: os advindos da body art, nas quais o corpo-sujeito é um suporte para intervenções; os processos de criação interferidos por alteradores de consciência; e os procedimentos voltados para os usos de hormônios (testosterona e estradiol). A ideia de um corpo entrópico como posicionamento político é aqui observado em paralelo e/ou confronto ao conceito de i-mundo, de Jean-François Mattéi, e como recurso para a discussão dos entendimentos de barbárie.

\section{Palavras-chave}

Performance; corpo; alteradores de consciência; estradiol e testosterona; política.

\begin{abstract}
The aim is to reflect on the approaches of controlled/uncontrolled modes in some artistic practices, from three assumptions: the arising of body art, in which the body-subject is a support for interventions; the creation process interfered by changers of consciousness; and procedures facing the uses of hormones (testosterone and estradiol). The idea of an entropic body as political attitude is observed in parallel and/or confrontation with the concept of i-world, by Jean-François Mattéi, and as resource for discussion on the understandings of barbarity.
\end{abstract}

\section{Key-words}

Performance; body; changers of consciousness; testosterone and estradiol; politics.

\footnotetext{
1 Professora de Figurino e Performance no Colegiado de Artes Cênicas da UNESPAR - Campus de Curitiba II - FAP.
} 
Postscriptum: Mantive-me em meu posto de figurinista. Em momento algum o abandonei. Isso tudo é sobre invólucros. Apontar um lápis é presenciar a saia das camadas de madeira que prontamente se modelam, essas mesmas camadas que prensadas formam canaletas para o grafite. Antes das madeiras os invólucros podiam ser cordas, e também essas cordas podiam ser feitas de intestinos de animais, crinas de cavalo, folhas e arbustos de bétula, zimbro ou salgueiro. E de cabelos humanos. Em tudo há invólucro. A alface, toda ela um vestido verde encrespado, ou os lírios nos campos. Mantive-me no meu posto. Dentro do corpo revestido pela pele, outros pequenos corpos revestidos por suas peles, e dentro dos pequenos corpos outros minúsculos corpos, e ovinhos-casquinhas-invólucros prontos para serem arrebentados. Um sem fim de invólucros.

Scriptum: Aqui deveria haver uma introdução, uma síntese ou ao menos alguma indicação sobre a estrutura do texto a seguir. Mas não está sendo possível. Não está. A estrutura diversas vezes desenhada e abandonada agora parece não querer tomar forma, e já sendo tarde, decidi deixa-la no sendo, no que é possível. Os recortes nada mais são do que um enfileiramento de flashes. É tudo quanto posso. Nas tentativas, havia selecionado as bibliografias e havia, sim, um norte claro: o livro de Jean-François Mattéi, $A$ barbárie interior: Ensaio sobre o i-mundo moderno, seria o condutor para as análises de algumas performances, sobretudo pelo seu conceito de i-mundo. Depois, percebi que seria trabalhoso adotá-lo como referência para contemplar as discussões mais recentes, as quais me propunha refletir. Seria necessário acompanhar também as críticas tecidas à marcada divisão entre o que o autor observa como sendo cultura verdadeira, reflexo do domínio da linguagem, versus a cultura de massa, passageira, a barbárie e, entre outros, seu posicionamento contundente sobre termos nascidos póstumos às ideologias, ao progresso, ao fim da história da arte e da metafísica, perdendo o sentido do começo. Mas insisti, por deferência à sua notória compilação de extratos poéticos, filosóficos e políticos, que juntos faceiam um arco histórico desde a antiguidade clássica ao contemporâneo. Pouco tempo depois tive que interromper a escrita, e quando a retomei nada mais fazia sentido.

Acordei numa tarde de sábado e poderia ter ouvido as palavras de Michel Foucault (2013: 05) "Basta eu acordar, que não posso escapar desse lugar que Proust [...] docemente, ansiosamente, ocupa mais uma vez em cada despertar". Então, desperta, repetiria com Foucault e Proust: "meu corpo é o contrário de uma utopia, é o que nunca está sob outro céu, é o lugar absoluto, o pequeno fragmento de espaço com o qual em sentido estrito eu me corporizo" (FOUCAULT: 2013: 05). Assim não o foi. Acordei ainda anestesiada, após uma histerectomia. Na cama ao lado, a moça que havia dado à luz ao garotinho que não queria aceitar seu peito para se alimentar. Durante toda a tarde e a noite conversamos e ela me contava algumas coisas sobre sua vida, e eu voltava a perguntar sobre essas mesmas coisas. As informações não se firmavam em mim. Virava-me e dormia. Aos poucos passei a ter mínima noção do meu corpo, da sonda posta para coletar a urina. E sim, aquele corpo era o meu lugar absoluto. Não havia sofrimento, eu-meu-corpo estava íntegro, num estado de plena vulnerabilidade. Íntegro na vulnerabilidade.

Recebo alta no dia seguinte. São as novas medidas para evitar infecções hospitalar. $\mathrm{Na}$ semana que segue, eu-meu-corpo nos perdemos e entramos em descompasso: passei a ter lembranças do meu corpo da semana anterior, e esse corpo de agora exigia um recomeçar. 
Recomecei. Abertura das Olímpiadas do Rio de Janeiro. Impeachment da presidenta Dilma Roussef. Sento-me à frente do computador para retomar o texto. Horas de repouso. Retomo 0 texto. Um pouco menos de repouso. Mais tempo no computador. Multidões na rua. Eumeu-corpo, aqui, isolado. A multidão se faz de cada um dos corpos lá presentes. Eu-meucorpo não estou presente. Começam os flashes. Mês de agosto, mês do cachorro louco: a Primeira grande Guerra Mundial iniciou-se no dia $1^{\circ}$ de agosto de 1914 . No dia 02 de agosto de 1934, Adolf Hitler se torna o Chefe de Estado da Alemanha. Nos dias 06 e 09 de agosto de 1945 as cidades de Hiroshima e Nagasaki foram atacadas por bombas atômicas. No dia 24 de agosto de 1954, o presidente Getúlio Vargas cometeu suicídio. No dia 13 de agosto de 1961, é iniciada a construção do Muro de Berlim. Mês de agosto de 2016, no Brasil: jornais publicam diariamente notícias do IMPEACHMENT da presidenta Dilma Roussef. Mês de agosto de 2016: os jornais do mundo inteiro noticiam o "impeachman" da presidenta Dilma Roussef (entre aspas e grifado). Mês dos cachorros loucos.

Descarto a listinha de nomes de performers dos anos de 1960 e 1970. Insisto apenas nas análises das ações de Gina Pane e Stuart Brisley por apego, e por considera-los representantes profícuos do início do debate, nas artes, que alcança a problemática da individualidade versus coletividade, já desde o período de estruturação das sociedades capitalistas. Paralelamente, a sensação de estar propondo um percurso desgastado, inúmeras vezes percorrido por autores de diversas áreas do conhecimento. As frases nos cartazes das manifestações parecem ter "jogado pó" nas ações dos artistas: "meu útero é laico", "a buceta é minha", "nem direita nem esquerda, somos um país inteiro", "vandalismo é morrer na fila de um hospital", "vandalismo é não falar de amor", "o estupro veio antes da minissaia". A objetividade das frases redimensionam as discussões da coletividade e, sim, redimensionam o sentido da barbárie. Talvez não exatamente assim. Um pouco mais complexo.

O livro Antropologia do corpo, de David Le Breton, seria outro norte para esse texto. Já na introdução, o argumento de Le Breton (2016: 07): "Viver consiste em reduzir continuamente o mundo ao seu corpo, a partir do simbólico que ele encarna". E mais adiante suas pesquisas se voltam para os entendimentos do corpo em sociedades não ocidentais, citando os canaques, melanésios da Nova Caledônia, para os quais a existência humana não se separa da existência das árvores, dos frutos, das plantas. Terminologias idênticas são usadas para designar as partes dos seus corpos, conforme esclarece Le Breton (2016: 19): "Kara designa, ao mesmo tempo, a pele do homem e a casca da árvore. A unidade da carne e dos músculos (pié) remete à polpa ou ao caroço dos frutos". A longa panorâmica traçada pelo autor percorre o imaginário do dentro e do fora do corpo, abrangendo os discursos da modernidade sobre as fragmentações e, posteriormente, a noção de máquina como organismo.

Revezando-me entre as leituras, o repouso e a visita às redes sociais, todas as imagens/informações embolaram-se, e não me foi possível separá-las. 0 cachorro louco estava à soltas. Toda vez que me deitava, ouvia seus latidos e apenas puxava a coberta, cobria a cabeça, tentando me isolar no/com meu pequeno lugar absoluto. No estado de vulnerabilidade, deixei-me levar por um grande flash.

Estamos na Idade Contemporânea. 
1789, França: Liberté, Égalité, Fraternité. Declaração dos Direitos do Homem e do Cidadão. Talvez fosse melhor: Égalité et Différence. 1865, EUA: fundada pelo general Nathan Bedford Forrest a primeira Ku Klux Klan. 1870, Alemanha: publicação do livro do ativista gay Karl Heinrich Ulrichs, intitulado Araxes: um Apelo à Libertação dos Uranianos das Leis Penais. 1876: EUA: promulgadas as leis Jim Crow, leis locais e estaduais que institucionalizaram a segregação racial. 1871, Brasil: Lei do Ventre Livre. 1881, Brasil: Lei Saraiva, e abolição do voto do analfabeto. 1885, Brasil: Lei dos Sexagenários. 1888, Brasil: Lei Áurea, a abolição da escravatura. 1891, Brasil: primeira Constituição Republicana: Art. 72 parágrafo $6^{\circ}$ será leigo o ensino ministrado nos estabelecimentos públicos. 1897, Reino Unido: fundação da União Nacional pelo Sufrágio Feminino, a favor do direito às mulheres ao voto. 1920, União Soviética: legalização do aborto. 1931, Áustria: Lili Elbe passa pela primeira cirurgia de redesignação sexual. 1933, Brasil: pela primeira vez a mulher pode votar. 1936, Alemanha: criação do Escritório Central do Reich para o Combate da Homossexualidade e do Aborto. 1940, Tuva: é nomeada a primeira mulher Chefe de Estado do mundo moderno. 1948, África do Sul: é iniciado o regime do Apartheid. 1948, Nona Conferência Internacional Americana: Declaração Americana dos Direitos e Deveres do Homem. 1955: EUA: Movimento dos Direitos Civis dos Negros dos Estados Unidos. 1960, EUA: liberação da pílula anticoncepcional. 1968, EUA: queima dos sutiãs, protesto das ativistas do WLM. 1969, EUA: Rebelião de Stonewall: manifestações dos membros da comunidade LGBT contra a invasão da polícia de Nova lorque. 1994, África do SUL: é nomeado o primeiro presidente negro da África do Sul. 1977, Brasil: sancionada a lei que instituiu o divórcio. 1997, Brasil: cinco jovens de classe média ateiam fogo no índio que dormia em um ponto de ônibus. 2001, Holanda: legalização do casamento entre pessoas do mesmo sexo. 2005, Bolívia: é eleito o primeiro presidente de origem indígena. 2006, Brasil: sancionada a lei Maria da Penha. 2009, EUA: é nomeado o primeiro presidente negro dos EUA. 2009, Berlim: a meio-fundista Mokgadi Caster Semenya é submetida a testes de gênero para comprovar sua feminilidade, após conquistar medalha de ouro no Campeonato Mundial de Atlestismo. 2009, Sudão: prisão de 13 mulheres por usarem calças compridas. 2014: Brasil: lei torna hediondo o crime de favorecimento da prostituição ou de outra forma de exploração sexual da criança ou adolescente. 2016, Brasil: assinado o decreto que permite que transexuais e travestis usem seu nome social em todos os órgãos públicos, autarquias e empresas estatais federais. 2016, EUA: atentado na boate gay em Orlando faz 50 vítimas. 2016, Brasil: a transexual Lea T participa da abertura das Olimpíadas do Rio de Janeiro.

Continuo acompanhando as notícias. Repouso cada vez menos. As portas dos armários que estavam abertas para que eu não fizesse esforço físico acima do recomendado, agora já podem ser fechadas. Caminho pela casa. Mas é difícil escrever. Escrever exige um esforço de todo o corpo. Fiz um exercício, tipo uma matrix: tentei projetar todas as ações costumeiras no ato de escrever num corpo mental. Não funcionou. Canso-me rapidamente. Não desisto de Gina Pane, tampouco de Mattéi.

Inicio: Se não for razoável afirmar com Mattéi que nascemos depois do fim, a Ação Sentimental (1973), realizada por Gina Pane, nos confirma que nascemos póstumos. Os vestígios de uma infinidade de corpos-mulheres se colam ao longo da pele de seu braço estendido diante do público, quando lentamente a artista craveja-o com espinhos. 0 legado 
de humilhações, torturas, privações ou conquistas de outros corpos-mulheres estão presentes por lembrança, e por continuidade. Pane é mulher. Seu corpo não se aparta, não se desvincula, e arrasta consigo o concernente a esse universo. Por recusa, ou por reiteração.

A ação segue. De posse de uma navalha, traça um corte em sua mão. As camadas de pele se abrem para deixar ver o corpo-Pane. Com o corte silencioso também se abre a perspectiva da separação. A artista está só. Ela é o seu corpo aberto, desnudo por uma ação violenta, ignóbil: sangue, veias artérias, tecidos, pus. Suspende-se momentaneamente o envoltório que unifica os corpos. Seu corpo desprendido do universal, da integralidade, quase um atentado contra o corpo, ou contra a vida.

O corte de Pane é a volta ao caos e à desordem. Koinônia, a comunhão, se reverte em negação e contemporização. É negação do pertencimento, da cordialidade, da condescendência, ao tempo em que contemporiza: o corpo aberto sela um pacto da mais profunda intimidade, se dá a conhecer, como em eucaristia. Conceitos e palavras ocupam 0 espaço da ação, aqueles não ditos, assim como conjuntos de leis e regras aos poucos vão se organizando e acentuam a brutalidade desse acontecimento.

Fixando marcos nos modos de apresentação do corpo em cena, também alude aos modos de controle da longa história da humanidade. Num primeiro momento estatutos e sentenças claras sobre o cuidado com os outros e o cuidado com o si, e em mensagem sublinhar: nós nos cuidaremos. 0 procedimento aberrante é metodológico, explicita diante do público a agressão, o desvio, a histeria. Invisíveis, mas presentes, oprimindo o corpo da artista, um amontoado incalculável de escritos, imortalizados ou poucas vezes ouvidos, mas sempre em zelo da simetria, como a organizar o traçado de um contorno, em que nada escape. Só há o dentro e o fora, da razão. No amontoado de escritos há um uníssono: nós nos cuidaremos, pelo bem da integridade. Qualquer atentado contra si é um ferimento, e cuidaremos dos ferimentos, dos seus ferimentos, para que seus dias se completem até o momento devido, ainda que se preciso for tenhamos que te amarrar em camisas de força, injetarmos entorpecentes em suas veias e te isolarmos, pelo bem comum, mas vigiaremos sempre as fronteiras para que não se borrem os contornos. Manter-nos-emos lúcidos, regrados. Refrearemos o i-mundo ou a des-medida.

No corte-desmedido de Pane, "ação sentimental", uma intensa batalha com o logos é travada, pois, como sugere a artista, é ação do sentimento, não da razão. Mas o logos subsiste pelo autocontrole necessário para que a ação aconteça. Adentrar seu próprio corpo, suas entranhas, a caverna, até o limite de si mesmo. Conhece-te a ti e aos teus limites.

Numa ação anterior, Homenagem a um jovem drogado (1971), Pane mergulha suas mãos em chocolate quente, enquanto lê um texto informando ao público ser essa a bebida matinal dos pais do jovem toxicodependente, encontrado morto. Em seguida, como num ritual, ingere o chocolate, em participação e a comungar o corpo esquecido, e da sua vida despercebida entre tantas outras. 
A denúncia sobre o estado de letargia da sociedade é feita com seu próprio corpo em martírio: "o objetivo de minhas experiências é desmitificar a imagem do 'corpo' como reduto de nossa individualidade, para restaurar sua verdadeira realidade, a função da comunicação social"2 (PANE, apud GROSENICK: 2002: 428). Em diversas entrevistas afirma que a preferência pelo termo "ação" em detrimento de "performance", se dá como uma cautela pela costumeira associação entre o segundo termo e atuação. No ato vivo, a artista não teatraliza. Há um duplo acontecimento: é o seu corpo que sente, ao tempo em que é o corpo-dor outrem, porque também ela é o outro diante do público.

Sua resposta é complexa: o macro é composto do micro, e a cura está no micro para se sanar o macro. A armadilha e o paradoxo do projeto da modernidade são escancarados: sua ação não pode ter como ponto de partida o universal, senão o seu próprio universo, e o seu próprio universo não pode descartar 0 universal. Na sua pele aberta é desfeito 0 revestimento-definição, e desfeito esse contorno da alteridade, seu território-corpo se alastra no dentro/fora, disposto à contaminação. Um penetrável.

Preciso descansar. As dores persistem. Três dias depois da cirurgia meu rosto inchou, meus traços se modificaram. Já não me reconhecia ao olhar no espelho. As mãos também incharam. Um grosseirão nas costas. Dificuldade para respirar. Era uma reação alérgica aos medicamentos. Suspendi os medicamentos. Estou vulnerável.

Releio o texto de Peter Kramer e Paola Bressan, Humanos como superorganismos. A noção de que somos indivíduos unitários é rebatida pelos autores quando anunciam: habitam em nós elementos humanos e não humanos, e nem sempre os elementos humanos estão no comando. Basicamente vivemos da interação desses elementos, por vezes entidades egoístas que quando em luta pelos seus interesses, passam a influenciar nossas emoções, cognições, comportamento e saúde. É da integração desses micro-organismos que podemos dizer quem somos. E somos uma quimera, mistura de corpos. Somos um coletivo, um superorganismo de micro-organismos em luta incessante pela sobrevivência. Somos hospedeiros de parasitas. Somos um campo de batalhas entre micróbios, vírus e células humanas desconhecidas. Em nós, criaturas exploram outras criaturas, para parasitá-las.

Stuart Brisley é um penetrável. No esteio da contracultura e influenciado pelas críticas ao capitalismo, sobretudo aquelas estruturadas a partir do marxismo, 0 artista britânico metaforiza em suas ações a apatia na qual a sociedade se vê imersa no início dos anos de 1970. Em sua ação And for today... nothing (1972), a audiência passa por uma porta entreaberta para encontrar um banheiro sujo e fétido, numa ambientação escura, e mais ao canto a banheira cheia de carnes em decomposição, boiando na água fria, e junto à outros excrementos, sangue e detritos, o artista deitado, submergido, por duas horas, durante dez dias. Moscas e vermes passam a fazer parte do quadro mórbido e repugnante.

Essa obra será a base do filme Arbeit Macht Frei (O trabalho liberta), frase que foi cunhada por uma associação étnica nacionalista, a Deutsche Schulverein de Viena. Adotado em 1928 pelo governo da República de Weimar, o slogan celebrava os feitos do governo na tentativa

2 "El objetivo de mis experimentos es desmitificar la imagen del 'cuerpo' como reducto de nuestra individualidade, para restaurar su verdadera realidad, la función de comunicación social". Tradução livre. 
de acabar com o desemprego, tornando-se ainda o slogan do Partido Nazista. Uma placa na entrada de quase todos os campos de extermínio, a exemplo de Aushwitz, indicava: "O trabalho liberta".

Aos menos duas frentes imediatas de leituras se abrem diante da ação de Brisley. Primeiramente como denúncia do processo escravagista, sutil ou não, na edificação do capitalismo, e a consequente alienação impressa nos corpos sob a ironia do slogan. Também em denúncia da vida tornada um detrito, um resto. A ação se aplica como um método igualmente hediondo para o público, obrigando-o a lidar com seu asco e repugnância, como medida extremada contra a morte das percepções, da solidariedade.

Disposto à contaminação por outros corpos, por outras identidades, rompendo os contornos da individualidade e rompendo hierarquias entre as naturezas, Brisley é um corpo-penetrável.

Volto a folear as páginas de Mattéi. Na retomada do mito grego, em determinada passagem, o comentário de Mattéi (2016: 101): "O kosmos aparece como a união das potências arcaicas da Terra e do Céu, saídas do Caos, e dos seres razoáveis, Mortais e Imortais, que a elas estão ligados em uma mesma koinônia". A construção de seus argumentos vai sendo feita lentamente, é preciso estar atenta, pois nas páginas iniciais estão as bases para a sua tese final. I-mundo, o fora do mundo (do cosmos), o que se desprende da totalidade. Ao menos um terço de sua obra se empenha em averiguar nos escritos filosóficos e nas leis da antiguidade clássica as indicações sobre a barbárie como sendo, ou não, uma noção do que é estrangeiro, do que não pertence. Os sistemas da língua são pontos de partida e seus domínios sempre determinantes para a classificação. Se o sistema da língua é social e não individual, as regras para o seu domínio se estabelecem tanto em um quanto em outro plano. Sócrates sentencia: "Conhece-te a ti mesmo". O mito da caverna, de Platão, respeita 0 individual, mas em expansão, e a sua "igualdade geométrica" - a justiça cósmica - é a medida da razão, uma dimensão universal, o ideal. Dos escritos de Sócrates, Mattéi destaca: "'A desordem e o desregramento', akosmian oude akolasian (...) 'o i-mundo ou a des-medida" (MATTÉl, 2016: 101).

\section{Surfarei por aí}

Assisto o vídeo de Timothy Leary, Como controlar seu cérebro. Imagens sobrepostas, luzes, flashes, música techno de fundo e a voz de Leary: "Isto é uma experiência sobre a formação da mente, in-formação, formação, controlando, operando sua mente e seu cérebro, utilizando técnicas digitais para sobrecarregar, bagunçar, confundir e desfocar sua mente. 0 estado natural do cérebro é o caos. (...) É necessário questionar tudo o que você foi ensinado, questionar a autoridade (...) aprender a se por em estado de compreensão vulnerável, caótica, confusa. (...) As palavras que você usa, os modos de comunicação que você usa, determinam as realidades que você habita". Não consigo ver tudo, fico com enjoo já nas primeiras imagens aceleradas.

O nome de Jack Kerouac tornou-se inseparável da legenda: "autor de On the road, livro-bíblia dos hippies, uma das obras máximas da geração beat, escrito sob os efeitos de benzedrina e café". Quase como um neon a piscar, essa legenda propaga diversas informações sobre 0 universo da criação nos anos de 1950 e 1960. Em Flashbacks, surfando no caos, de Timothy 
Leary, são oferecidos dados sobre o contexto em que o livro foi escrito, fazendo dissolver certa camada simplista que se associa a essa descrição.

Psicólogo e professor da Harvard, Leary foi um dos primeiros pesquisadores a investir no uso de drogas alucinógenas como processo de autoconhecimento. Acompanhar as páginas de seu livro é acompanhar uma lista imensa de nomes ligados pela tentativa de encontrar outros modos de desenvolvimento da mente humana. Escondidos entre as muitas passagens de sua vida, esses nomes circunscrevem as esferas da medicina, política (a exemplo da CIA e da indústria farmacêutica), artística e outras, numa trama de interesses divergentes.

Mostrando ser um truísmo que gerações anteriores de artistas sempre fizeram uso de alteradores de consciência, Leary (1999: 52) cita um de seus rituais, no qual Aldous Huxley, responsável por guiar o experimento, leu uma descrição das técnicas utilizadas pelo Clube do Haxixe (1844), em Paris, com a presença de Baudelaire. Também eram frequentadores do clube Théophile Gautier, Alexandre Dumas, Flauber, Balzac e o pintor Delacroix, tendo por mentor o doutor Jacques-Joseph Moreau, um dos precursores da psiquiatria e obstinado por desvendar as causas da loucura. A maioria desses escritores fez menção, em seus romances, ao uso de alteradores, como é o caso de Baudelaire em Paraísos Artificiais.

Kerouac, no entanto, chegou à popularidade pela combinação de vários fatores. A escrita autobiográfica relata a viagem de sete anos pelos Estados Unidos, com frequentes idas ao México, na companhia de seu amigo Neal Cassady. Projetando-se em seu alter ego, o personagem Sal Paradise, descreve suas aventuras ao lado de Dean Moriaty (Neal Cassady). A tensão entre ficção e realidade é afrouxada, gerando aproximação do leitor com um estilo de vida apreciado pelos jovens da época, o "pé na estrada" (on the road). Essa sobreposição de identidades, a real e a ficcionalizada, fortalecem os relatos da vida nômade, os usos de drogas, do encontro com pessoas incomuns, dos submundos, enfim, da tão sonhada liberdade em oposição aos ideais do sonho-americano, da estabilidade financeira, da propriedade e da família, de seus costumes e valores.

Enquanto o personagem Sal se aventura por um mundo inusitado, seu criador aventura-se com ele sob os efeitos causados pelas substâncias psicotrópicas, e vice-versa. Acrescentase ainda que a escrita em "estilo-avalanche", quase um fluxo de consciência, sem as pontuações e parágrafos, também cria uma cadência própria desse estado alterado, muito embora a obra tenha sido revisada para a publicação em 1957, havendo modificações exigidas pelos editores.

Metáfora ou literalidade do autoconhecimento, a viagem de Sal integrou um imaginário que há tempos vinha sendo edificado na sociedade norte-americana, não restrita ao campo das artes, alcançando filósofos e acadêmicos, conforme explicita Leary (1999: 58): "Estávamos usando as drogas para reafirmar, nos termos da psicologia moderna, a visão platônica-pagãgnóstica de um mundo 'interno', que conteria o mapa que nos possibilitaria compreender, colaborar e nos harmonizar com as leis físicas do mundo externo".

A política do êxtase, seu livro publicado em 1968, prega pelo direito de conhecer e reorganizar o cérebro, ampliando os seus limites, em contraposição à massificação, já 
extremada com a popularização dos meios de comunicação, sobretudo a televisão. E foi na companhia de Allen Ginsberg que surgiu o que seria o ponto central desse livro: a Quinta Liberdade, 0 direito de auto gerenciar 0 sistema nervoso, o direito a que todos pudessem optar por ingerir drogas de expansão da mente. A Quinta Liberdade é uma referência ao discurso do presidente Flanklin Delano Roosevelt, pronunciado no dia seis de janeiro de 1941, conhecido como o Discurso das Quatro Liberdades, em que se consta: a liberdade de expressão, a liberdade religiosa, a liberdade de viver sem penúria e a liberdade de viver sem medo.

Sua vivência em um ambiente acadêmico permitiu-lhe parcerias que foram definitivas, a exemplo do antropólogo, historiador e linguista da Universidade do México, o professor Gerhart Braun, que facilitou seu contato com a cultura mexicana, e as experiências com os cogumelos em Cuernavaca, no ano de 1960. Médicos, psicólogos, psiquiatras, dentista, artistas, cientistas, políticos, militares, todos há tempos empenhados em entender os processos da mente. Leary credita à CIA a responsabilidade pelos usos indevidos e a favor de uma política de controle:

Como ficou comprovado mais tarde, a CIA merece o crédito pela criação da cultura de drogas dos anos 60. Na sua tentativa de varrer o planeta em busca de qualquer raiz, chá, erva ou folha que pudesse entortar a cabeça das pessoas, a CIA impulsionou as disciplinas de etnobotânica e psicofarmacologia um século à frente.

A CIA patrocinou dezenas de experiências com drogas, inundando centros de pesquisa conservadores com milhões de doses de LSD. Os cientistas mais experientes, logicamente, passavam as drogas para os seus assistentes, que as administravam em si mesmos ou em seus amigos. Ken Kesey e Allen Ginsberg estavam entre os muitos pacientes que receberam de bom grado a dádiva da Agência. (LEARY: 1999: 79).

A política do êxtase propõe uma unificação do individual e do coletivo. Não raramente, seus intuitos foram descritos como uma releitura de Sócrates e Platão, mas recebendo críticas pelo tom messiânico.

Um resumo rápido da biografia de Leary pareceria paradoxal, pois os anos de 1980 e 1990 foram dedicados à cibercultura. Seguindo de perto, no entanto, percebe-se que as suas preocupações estavam ligadas às possibilidades de controle do indivíduo de forma ampla, e todas as adaptações que fossem necessárias para desenvolver suas críticas, certamente seriam feitas. Adotado como tecnoxamã dos Modernos Primitivos, torna-se um dos forjadores da psicologia futique (combinação de futuro e antigo). Cria softwares de design para navegação nas redes, como possibilidade de locomoção no espaço cibernético, com 0 objetivo de inundar o cérebro por ondas oscilatórias de dados eletrônicos.

Em seu último livro Projeto para morrer, escrito meses antes da sua morte, no ano de 1996, intenta, assim como dito no título, ser um projeto que abre novas perspectivas para 0 entendimento da morte, e seus planos ali expostos foram concretizados: sua cabeça foi retirada e congelada para estudos posteriores. $O$ restante do corpo foi cremado e as cinzas libertas no espaço pela nave Pegasus. 
$\mathrm{Na}$ relação com os Modernos Primitivos aproximou-se de Le Breton, que por essa época refletia sobre os adeptos da body modification, da bodybuilding e dos hackers do corpo, esses mesmos que militavam em favor do direito de tomar o seu próprio destino pelas mãos, de modificar seus corpos, de serem donos legítimos de si mesmos. E mais adiante Leary acompanhou, também com Le Breton, os simpatizantes do adeus ao corpo, os neos descartianos que viam no corpo uma prisão de carne e de sangue.

Leonardo, o garotinho que nasceu na madrugada em que fui internada, ocupa meus pensamentos sempre e sempre. Durante todo aquele dia e aquela noite ele não quis mamar. Na manhã do dia seguinte, a médica explicou para a mãe que ele ainda não tinha percebido que não estava mais em seu útero. Tomando a medida necessária, tirou toda a sua roupa para que sentisse frio e fosse estimulado seu instinto de sobrevivência. Estávamos no inverno, com temperaturas por volta de seis graus, num quarto sem aquecimento. A mãe ajudou a tirar as roupas de seu filho, pois não havia nada que pudesse fazer por ele.

Rubrica da peça Valsa N ${ }^{0} 06$ de Nelson Rodrigues:

(Cenário sem móveis. Apenas um piano branco. Fundo de cortinas vermelhas. Uma adolescente sentada ao piano. Vestida como que para um primeiro baile. Rosto atormentado, que faz lembrar certas máscaras antigas. Mãos pousadas sobre as teclas. Ao fundo, o rumor do bombo, que acompanhará toda a ação. Ao abrir-se o pano a cena está mergulhada na sombra. Apenas uma única luz, incidindo sobre o rosto da mocinha. e, então, ela executa um trecho da valsa $n^{\circ} 6$, de Chopin. Seu rosto passa a exprimir paixão, quase o êxtase amoroso. Corta bruscamente a música. llumina-se 0 resto do palco. A mocinha ergue-se, sem sair do lugar. Terror).

O espaço de transição entre a vida e a morte. O passamento. Imagens fragmentadas. Rostos. Palavras. Um vestido. Um espartilho. Partes do corpo boiando pelo ar. A névoa, e tudo se foi. $O$ paletó. $O$ sapato. Sônia. Um punhal, e a valsa. Sempre a mesma valsa. A vergonha de tudo. Dos próprios pés. Dos móveis nus. Um punhal cravado no nome Sônia. E a valsa. Sônia!... Sônia!... Sônia!... Quem é Sônia?

No palco, a performer transexual Leonarda Glück pronuncia cada uma das palavras indicadas pelo autor, na montagem de Valsa $n^{\circ} 6$, de Nelson Rodrigues, sob direção de Gustavo Bittencourt, em 2012. As rubricas seguidas quase que literalmente. Os recursos cênicos parecem não distar daqueles usados em 1951, ano em que o autor escreveu o texto. 0 palco italiano. A cortina vermelha. O piano. A atriz/performer sozinha em cena. Os personagens vão surgindo aos poucos, mas se trata de um monólogo. São os delírios. Ou, na fala do autor: "Uma pessoa individuada - substancialmente ela própria - e ao mesmo tempo uma cidade inteira, nos seus ambientes, sua feição psicológica e humana" (RODRIGUES: 1951:02). Ou a personalidade múltipla. Ou, a não individuação. Recurso cênico: desdobramento da atriz em vários personagens. Parece pouco. A cidade inteira, nos seus ambientes. A humanidade inteira, nos seus ambientes. Apenas os rastros da humanidade, na voz de Sônia para si mesma: "num mundo em que tudo que resta das pessoas são os nomes". Do emaranhado, a história vai sendo reconstruída. A posta em 
cena de Bittencourt redimensiona a cortina vermelha, o palco italiano, o piano branco, a luz que incide sobre o rosto. Entre as referências de pesquisa do diretor aparece o nome do cineasta Dario Argento. Sim, as referências surgem no ambiente inóspito, misterioso. E o espectador a testemunhar o impacto das sensações, um arrepio sempre latente, pronto para se formar. Emprestado de Dario Sargento: um thriller, slach ou film d'exploitation.

Em meio às frases desconexas, a violência, pedofilia e adultério. Mas ressoa a pergunta: quem é Sônia? A adolescente de 15 anos em conflito? Em transição. Só sabemos da transição. Repetido várias vezes no texto: "é a idade, a transição". A transição é a palavrachave a que logo se tem acesso, e o diferencial na direção de Bittencourt, que cria um vínculo entre Leonarda e Sônia, que as une, e que as separa.

No início do segundo ato, Leonarda/Sônia deita-se, afasta as roupas e se auto injeta um miligrama de estradiol. 0 hormônio permanecerá por vinte e oito dias em seu corpo, alcançando o ápice no décimo dia. Mesmo à vista do espectador, talvez permaneça a incógnita do que havia na seringa. A ação lembra os procedimentos de film d'exploitation, entre a ficção e a realidade, e os temas tabus, explícitos, sem rodeios. Contra todos os procedimentos que seguiram de perto a rubrica do autor, a injeção de hormônio põe a cena em suspenso, cria um vácuo no espaço de tempo, e os vinte e oito dias se condensam no tempo real da ação.

Há, sim, a camada simbólica. E também ela causa zonas intermediárias. A transição do corpo criança/adolescente/mulher. $O$ estradiol e a progesterona assegurando 0 crescimento dos seios, dos pelos do corpo, 0 alongamento das trompas. 0 óvulo em maturação, a engrossar 0 endométrio. A vida fértil da mulher. Sônia. $O$ corpo de Leonarda na transição de Sônia, passando pela sua transformação, quase um naturalismo levado ao extremo.

Em outra camada, Leonarda se coloca a si mesma em transição. Nos vinte e oito dias seguintes da apresentação, seu corpo sofrerá as mudanças iniciadas ali em cena. A sensibilidade aguçada, a diminuição dos pelos, o choro incontido e a libido menos latente. Em cada um desses dias a conexão com a transição de Sônia, em dilatação do tempo/espaço da arte, da vida.

Quem é Sônia? Mistura dos corpos? Identidades cruzadas?

Revisito o Manifesto contrassexual: práticas subversivas de identidade sexual, de Paul Beatriz Preciado. Coloco o meu dedo no local indicado (cu) na capa do livro, e atravesso-o até 0 fim. A contrassexualidade em substituição à noção de Natureza, tornada um contrato social, e a busca de corpos falantes, acima das normatividades inscritas nos corpos como verdades biológicas. No diálogo com as teorias de Judith Butler, Michel Foucault, Donna Haraway, Gilles Deleuze, Karl Marx, Jacques Derrida e outros, sua tese se sustenta na "contraprodutividade, isto é, na produção de formas de prazer-saber alternativas à sexualidade moderna" (PRECIADO: 2014: 22). O sexo é uma tecnologia biopolítica, e a contrassexualidade observa as transformações dos corpos sexuados e generalizados, visando um sistema tecnológico mais amplo, de modo a alcançar os "corpos intersexuais, 
hermafroditas, loucas, caminhoneiras, bichas, sapas, bibas, fanchas, butchs, histéricas, saídas ou frígidas, hemafrodykes" (PRECIADO: 2014: 27). Se trata de uma estratégia marxista. A Dildotectônica, contraciência que estuda o surgimento, a formação e a utilização do dildo (pênis de borracha), também se responsabiliza pela identificação de tecnologias de resistência e "os momentos de ruptura da cadeia de produção corpo-prazer-benefício-corpo nas culturas sexuais hétero e queer" (PRECIADO: 2014: 49). É uma estratégia marginal pela política do desejo. Símbolo de suplemento, o dildo questiona o lugar do masculino como sendo o de posse e propriedade. Vou seguindo o capítulo Práticas de inversão contrasessual, um quase manual de utilização do dildo. Interrompo a leitura. O livro de Preciado é um penetrável.

Leio o índice de seu outro livro, Texto Yonqui. Seleciono algumas palavras-chave: micropolítica farmacopornográfica; intoxicação voluntária; mutação; princípio autocobaia; exercícios de programação de gênero postporno; bioterrorismo de gênero; políticas do cuidado; foda-se a si mesmo; bruxaria narcótico sexual; vídeo-penetração. Leio a Introdução:

\begin{abstract}
Esse livro é uma autoficção. Se trata de um protocolo de uma intoxicação voluntária a base de testosterona sintética que concerne o corpo e os afetos de B. P. É um ensaio corporal. Uma ficção, é certo. Em todo caso, e se for necessário levar as coisas ao extremo, uma ficção autopolítica ou uma ficção autoteoria. Durante o tempo em que dura esse ensaio sucedem duas mutações externas no contexto próximo do corpo experimental, cujo impacto não havia sido calculado. Nem foi podido computar-se como parte desse estudo, mas que constituem os dois limites em torno dos quais se adere a escritura. (PRECIADO: 2008: 02)
\end{abstract}

Os diversos platôs estão dados. Por instantes me perco nas associações: Bobby, 0 adolescente cowboy de ciberespaço, de Count Zero, de William Gibson, que usa um IceBreaker fodão, um tipo de biochip que protege os dados na matrix. Júlia, a garota de Céu em chamas, de Rachel Pollock, que vai logo falando: "às vezes eu penso no meu clitóris como um imã, me arrastando para revelar novos depósitos de minérios nas minas da fantasia". Michel Foucault (1979: 18): "A história ensina também a rir das solenidades da origem. A alta origem é o exagero metafísico que reaparece na concepção de que no começo de todas as coisas se encontra o que há de mais precioso e mais essencial". A pergunta de Gilles Deleuze (2006: 337) "E quanto a você? Que são suas máquinas desejantes?" Índice do segundo capítulo de Os Kama Sutra (1976: 20): Do abraço. Do beijo. Da pressão ou da marca das unhas. Da mordida, dos artifícios do amor, segundo as mulheres de diferentes nações. Das várias maneiras de deitar e dos diferentes modos de união. Das diferentes maneiras de dar palmadas e dos sons que lhes correspondem. Das mulheres que agem como homens. Da introdução do lingam (membro) na boca. Como iniciar e findar uma união. Diferentes espécies de união e desavenças amorosas. Mary Shelley (2001: 54): "Tanto tem sido feito, exclamava a alma de Frankestein - mais, muito mais eu conseguirei; seguindo pelos passos já marcados, eu abrirei um novo caminho, explorarei forças desconhecidas, e desvelarei ao mundo os mais recônditos mistérios da criação". Hélio Oiticica: "Seja marginal, seja herói". Gilles Deleuze (1988: 32): "Trata-se de produzir, na obra, um movimento capaz de comover o espírito fora de toda a representação; trata-se de fazer do próprio movimento uma obra, sem interposição". 
Os platôs se intercruzam. Os diversos postos ocupados por Preciado (artista, pessoa comum, biólogo, escritor de ficção científica, teórico) redimensionam e jogam cinzas sobre 0 amontoado de leis, regras, escritos e obras. Mas depois, sopram essas cinzas e com elas trava um profícuo debate.

Seu corpo penetrável, sujeito à contaminação, em expansão, em crítica à política do controle, sem separação entre a vida e a arte, entre a prática e a teoria, entre o humano e o inumano, entre homem e mulher, entre a obra e o criador, entre o corpo e a mente, entre o pensamento e a ação. $O$ corpo de dentro dessacralizado, reorganizado, em redefinição flutuante. Um corpo de passagem. Um corpo nômade.

Em $O$ condicionamento (1972), Pane faz um mea-culpa pela violência da sociedade: deitase sobre um estrado de ferro, tendo embaixo quinze velas acesas a pouca distância de sua pele. Seu corpo é um lugar de rebelião, de violência, do abuso de si. Mas é o lugar da redenção: "quando abro meu 'corpo', de modo que podeis ver ali seu próprio sangue, eu faço por amor a vocês, por amor ao outro" (PANE, apud GROSENICK: 2002: 428).

Preciado não se martiriza, não se mutila, não se pune. Seu projeto de redenção prevê mudança no enunciado, pela experimentação das posições de poder, sem, contudo, reivindicar segregação, ou pondo em risco a alteridade:

Não me interessa o que é meu, o individual, mas como são atravessados pelo que não é meu. Por aquilo que emana pela história do planeta, da evolução das espécies vivas, dos fluxos econômicos, dos resíduos e das inovações tecnológicas, da preparação das guerras, do tráfico de escravos e de bens, das instituições penitenciárias e de repressão, das redes de comunicação e vigilância, da produção de hierarquias. (PRECIADO: 2008: 02

Também não se põe como corpo-resquício de um passado sempre contínuo. Nem mesmo supõe ser um corpo-futuro, de um mundo ainda por vir. Inicia-se no presente e nele permanece, consoante a outros corpos contemporâneos aos seus, no indicativo de adeus à concepção de corpo definido na modernidade. Não o adeus ao corpo premeditado por Leary, os neos descartianos e Le Breton, a prisão de carne e de sangue. Seu projeto é o de um corpo-mente alterado, readaptado e, sim, comunga com Leary a intenção de tomar o destino pelas mãos. Preciado é seu corpo-laboratório criado por ele mesmo. Assina seu protocolo. Uma mutante, para além da androginia, em defesa da Quinta Liberdade.

Em paralelo à leitura dos livros de Preciado, mantive abertas as páginas de $A$ barbárie interior: Ensaio sobre o i-mundo moderno, de Mattéi. Niilista em sua análise sobre o sujeito como projeto da modernidade em completa distinção ao da antiguidade clássica, o autor resume: "passagem insensivel da substancialidade à subjetividade ou, para dizer numa linguagem menos severa, da passagem da alma ao eu e, ao mesmo tempo, da passagem da exterioridade à interioridade" (MATTÉl: 2016: 147). Os argumentos seguintes persistem nesse ínterim da separação do sujeito do mundo substancial, lembrando sempre que a barbárie não é senão a dissociação do ser. Pane, Brisley, Kerouac, Leary, Leonarda, os Modernos Primitivos, os Hackers do Corpo e Beatriz Preciado, entre tantos outros, também 
questionam a dissociação do ser, mas não pela via do saudosismo que mantém silenciados os corpos dissonantes.

No meio da multidão de manifestantes no dia sete de setembro, o cartaz onde se lê: "vandalismo é morrer na fila de um hospital", atualiza de modo corriqueiro a discussão da barbárie. As barbáries implícitas de todos os dias, e que nos passam apenas como flashes.

Mantive-me no posto de figurinista. Apenas me coloquei no lado de dentro das camadas que revestem o corpo. Penetrei os invólucros. Leonardo Boff reflete sobre as percepções dos astronautas ao verem o Planeta Terra sob outro ângulo. 0 astronauta Salman al-Saud relatava: "No primeiro e no segundo dia, nós apontávamos para o nosso país, no terceiro e quarto para o nosso continente; depois do quinto dia tínhamos consciência apenas da Terra como um todo" (BOFF: 2012: s/p). A camada azul que reveste a Terra, o macro invólucro de tantos micros invólucros.

\section{Refêrencias}

BOFF, Leonardo: O sentido de ver a Terra fora da Terra. Disponível em: https://leonardoboff.wordpress.com/2012/11/28/o-sentido-de-ver-a-terra-de-fora-da-terral Acesso em 28 de agosto de 2016.

DELEUZE, Gilles. A ilha deserta e outros textos. Trad. Luiz B. L. Orlandi. São Pulo: lluminuras, 2006. Diferença e repetição. Trad. Luiz Orlandi, Roberto Machado. Rio de Janeiro: Graal,

\section{8.}

FOUCAULT, Michel. Corpo utópico, as heterotopias. Trad. Salma Tannus Muchail. São Paulo: N-1 Edições, 2013.

GIBSON, William. Count Zero. Trad. Carlos Angelo. São Paulo: Aleph, 2008.

GROSENICK, Uta. Mujeres artistas de los siglos XX y XXI. Madri: Taschen, 2002.

Microfísica do poder. Trad. Roberto Machado. Rio de Janeiro: Graal, 1979.

KRAMER, Peter; BRESSAN, Paola. Humans as superorganismo: how microbes, viroses, imprinted genes and other selfish entities shape our behavior. Padova, Perspctives on Psycological Science, 2015, v.10.

KEROUAC, Jack. Pé na estrada. Trad. Eduardo Bueno. Porto Alegre: L \& PM, 2013.

LEARY, Timothy. Flashbacks: Surfando no caos. Trad. Hélio Melo. São Paulo: Beca Produções Culturais, 1999

The policts of ecstasy. Berkeley, California: Ronin Publishing, 1998.

LE BRETON, David. Antropologia do corpo. Trad. Fábio dos Santos Creder. Petrópolis, RJ: Vozes, 2016.

MAGALDI, Sábato (Org). Teatro completo de Nelson Rodrigues. Rio de Janeiro: Nova Fronteira, 1981. MATTÉl, Jean-François. A barbárie interior: ensaio sobre o i-mundo moderno. Trad. Isabel Maria Loureiro. São Paulo: Editora UNESP, 2012.

PRECIADO, Beatriz. Testo Yonqui. Madri: Espasa Calpe, 2008.

Manifesto contra-sexual: práticas subversivas de identidade sexual. Trad. Maria

Paula Gurgel Ribeiro. São Paulo: N-1 Edições, 2014.

POLLACK, Rachel. "Céu em chamas". In: RUCKER, Rudy; WILSON, Peter Lamborn; WILSON, Robert Anton (Org). Futuro proibido. Trad. Sergio Kulpas, Ludimila Hashimoto Barros e Alexandre Matias. São Paulo: Conrad Editora do Brasil, 2003. 
SHELLEY, Mary. Frankestein. Trad. Mécio Araújo Jorge Honkins. Porto Alegre: L\&PM, 2001.

XAVIER, Raul S. (Org). Os Kama Sutra. Trad. Raul Xavier. Rio de Janeiro: Livros do mundo inteiro, 1976.

Artigo recebido em maio de 2017. Aprovado em outubro de 2017. 